\title{
MANAGEMENT OF A CASE OF LUMBAR STENOSIS WITH AYURVEDIC INTERVENTION
}

\author{
RATHA KSHIROD KUMAR*, BARIK LAXMI DHAR, HAZRA JAYRAM
}

Department of Clinical Research, National Research Institute of Ayurvedic Drug Development, Bidhannagar, Kolkata - 700 091, West Bengal, India. Email: drkkratha@gmail.com

Received: 27 June 2016, Revised and Accepted: 04 July 2016

\section{ABSTRACT}

Ayurveda intervention is gaining popularity for chronic and degenerative disorders. Lumbar stenosis is narrowing of spaces of lumbar spine cause morbidity in old age. Surgical laminectomy is the only answer in conventional therapy. However, the disease can be better managed in Ayurveda through panchakarma and rasayana treatment.

Keywords: Low back pain, Lumbar stenosis, Panchakarma, Katigraha.

(C) 2016 The Authors. Published by Innovare Academic Sciences Pvt Ltd. This is an open access article under the CC BY license (http://creativecommons. org/licenses/by/4. 0/) DOI: http://dx.doi.org/10.22159/ajpcr.2016.v9s2.13727

\section{INTRODUCTION}

Lumbar stenosis is the narrowing of spaces in the spine, which causes pressure on the spinal cord and nerve roots; cause pain along the back of the leg. The potential causes of the disease are aging, trauma, arthritis of spine, spondylolisthesis, regional tumor, and rarely due to the congenital origin. Pain, compression symptoms, and difficulty in walking are the usual symptoms of the disease. It is diagnosed from history, physical examination, and imaging studies. It is managed with physiotherapy, non-steroidal anti-inflammatory drug (NSAID) medications, and surgical laminectomy in the conventional system of medicine $[1,2]$. In Ayurveda, from the nature of the disease, it has clinical resemblance with Katigraha and Gridhrasi. Katigraha and Gridhrasi both mentioned in ayurvedic classics under Nanatmaja Vatavyadhi. Katigraha is very symbolic for restricted movement of the pelvic girdle. As kati (lumbar spine) one of the major seats for vata dosa, the vata dosa gets vitiated at its own seat. Gridhrasi is a form of the pain of lumbosacral origin (sciatica) usually radiates to knee or up to foot depending on the site of nerve root involvement. It is found in $5-10 \%$ of patients with low back ache. The cardinal features include ruk (pain), toda (pin and needle sensation), stambha (stiffness), muhuspandana (twitching and cramping) in the sphik (buttock), kati (waist), uru (thigh), janu (knee), jangha (calves), and pada (foot) [3-5]. The ayurvedic treatment consists of both the conditions are snehana (oleation therapy), swedana (sudation therapy), vasti (medicated retention enema), agnikarma (therapeutic cautery), and vatahara shaman yogas (palliative care) [6,7]. Clinical studies with ayurvedic formulation and panchakarma therapy are done by many scholars. Evidence on the evaluation of the ayurvedic intervention in lumbar stenosis has not been documented; hence, the communication is endorses a step towards the validation of use of the ayurvedic intervention.

\section{CASE REPORT}

\section{Presenting concern}

A 70-year-old man of Kolkata metropolitan area presented with history of low back and left leg pain for 5 years admitted to the hospital (OPD Regn. No. 6508/15-16 and IPD Regn. 162) of National Research Institute of Ayurveda for Drug Development, Kolkata. Feels fatigue while trying to lift something and have numbness of left foot. No complaint of radiating pain in lower limb. The pain increases on bending, standing, and walking. Activities of daily living are limited. No h/o of significant bowel and bladder disturbances. No h/s/o neuro deficit.

He had H/o trauma, in 1967, and underwent decompressive lumbar surgery (lumbar laminectomy) in 1997 - did well-good relief of leg symptoms - now having progressive back pain and some deformity.
Not known diabetic. Known hypertension since 1992 and regularly on antihypertensive agent. Diagnosed hypothyroidism in 2003 and on thyroxine supplement. No addiction, sleep disturbed, and using sleeping pill on regular basis. Bowel-irregular, appetite-normal, bladder-normal, good socioeconomic status, family history not suggestive.

Treatment h/o consists hot compression, using L/S brace, avoid floor sitting, rest, calcium and vitamin D3, vitamin B12 and E supplement, physiotherapy, but the pain has not improved much. He was advised decompression with or without fixation.

General examination and assessment through ayurvedic parameters

Pulse - 64/minutes, regular, blood pressure - 140/70 $\mathrm{mmHg}$, height - $170 \mathrm{~cm}$, weight - $69 \mathrm{~kg}$, urine (Mutra) - usual, stool (Mala) - hard (Badhha), Jivha - moist, sound (Shabda): Usual, Sparsa (Touch): Tender on painful areas, eye (Netra) - usual, stature (Akriti): Normal, skin (Tvak) - snigdha, nail (Nakha) - no abnormality seen.

Prakriti: Sharirik - Vatapaittik, Manshik - Rajashik, homologous (Satmya) - Madhyama, compactness (Samhanana) - Madhyama, digestion (Aharashakti) - Madhyama, exercise (Vyayama Shakti) - Avara, age (Vaya) - Vridhha, locality (Desha) - Anupa, period (Kala) - Chirakari, bowel (koshtha) - krura. Dosa - vata, dushya - asthi, majja, place of origin (Adhisthana) - kati and Trika Sandhi, Srotas - Asthivaha, Srotodusti - Sanga.

\section{Local examination}

No swelling/scar/sinus, scoliosis \pm , no gross neurodeficit, lumbar kyphosis with flat back, scoliotic deformity of the lumbar spine with convexity to right, diffuse tenderness of lower lumbar spine, limitation and painful range of movement (ROM) of lumbar spine, B/L straight leg raise (SLR)-positive, No distal neurological deficits, gait-painful.

\section{Laboratory investigation}

BMD-T score - 0.5, Z score - 1.2, human leukocyte antigen B27 - negative, thyroid-stimulating hormone - 0.352, FT4 - 1.6, fasting plasma glucose - 105 , serum creatinine - $0.9 \mathrm{mg} / \mathrm{dl}$, total cholesterol - $147 \mathrm{mg} / \mathrm{dl}$, trigyceride - $75 \mathrm{mg} / \mathrm{dl}$, high-density lipoprotein cholesterol - $54 \mathrm{mg} / \mathrm{dl}$, low-density lipoprotein cholesterol - $82 \mathrm{mg} / \mathrm{dl}$, fasting blood sugar - $108 \mathrm{mg} / \mathrm{dl}$, hemoglobin (Hb) A1C - 5.2\%.

Magnetic resonance imaging LS spine (2011)-L2-L3, L3-4, L4-5 level secondary canal stenosis causing compression on the thecal sac, lateral recesses, and the traversing L3 and L5 nerve roots, being most marked on left L5 root. 
X-ray dorsal spine-gross scoliosis of the dorsolumbar spine with spondylosis.

X-ray LS spine AP/lat view (2011)-showing evidence of L5 laminectomy with posterior lumbar fusion. Degenerative changes present with lumbar kyphosis. Mild L4/5 and L5/S1 compression. Gross scoliosis of dorsilumbar and spodylosis with convexcity to right. Sacroiliac joint normal.

\section{Assessment criteria}

The patient was assessed on the basis of grading of chronic low back pain $[8,9]$ and local examination of spine; on the day of admission to the IPD, on the day of discharge from the IPD, and on the day of subsequent follow-up after 1 month.

\section{Case conception and treatment selection}

On the basis of presenting history, physical examination, and ancillary investigation, the case was diagnosed as lumbar stenosis. Trauma and age are the etiological factors responsible for the genesis of the disease.
Vata is the prime dosa gets aggravated due to both, causing degenerative changes and compression symptoms. Vata primarily aggravated at its own site, i.e., Trika and Kati pradesha. To pacify the vata dosa snehana (Abhyanga and Kativasti), swedana (patrapindasweda) given to the patient and palliative care including rasayana oushadhi choosen as preventive measures.

\section{Treatment plan}

The following treatments were administered to the case consecutively.

1. Amapachana and Agnisambardhana: It was done with Chitrakadi Gutika 500 mg b.i.d. after food for 7 days with lukewarm water

2. Sarvang Abhyanga and Patarpindasweda: Abhyanga done throughout the body approximately for 30 minutes with Balaswagandhadi Taila. After Abhyanga, the patient was subjected to Patarpindaswedana for approximately 10 minutes. The whole procedure was repeated for 7 days

3. Kativasti with Ksheerabala Taila 30 minutes/day for 7 days

4. Virechana-Gandharvahastadi Eranda Taila $30 \mathrm{ml}$ start in the morning for 1 day

Table 1: Intensity of pain

\begin{tabular}{lllll}
\hline Serial number & Feature of pain of the case & $\mathbf{2 . 1 2 . 2 0 1 5}$ (grade) & $\mathbf{6 . 1 . 2 0 1 5}$ (grade) & Follow-up on 5.2.2016 (1 $\left.{ }^{\text {st }}\right)$ \\
\hline 1 & $\begin{array}{l}\text { Pain on thigh muscles while walking or when } \\
\text { standing up from sitting position }\end{array}$ & 3 & 0 & 0 \\
2 & $\begin{array}{l}\text { Feeling pain while walking slowly in the } \\
\text { upper region of the groin and near pelvic area }\end{array}$ & 2 & 0 & 0 \\
3 & $\begin{array}{l}\text { Feeling pain while turning the body on the } \\
\text { left side }\end{array}$ & 1 & 0 & 0 \\
4 & $\begin{array}{l}\text { Feeling pain when moving the waist either } \\
\text { side while lying on bed } \\
\text { Feeling pain while bending the head at the } \\
\text { time of washing the mouth, etc., and on } \\
\text { backside }\end{array}$ & 3 & 0 & 0 \\
Pain while wearing belt on the left side & 2 & 1 & 0 \\
\hline
\end{tabular}

Grading of chronic (LBP) pain: Von Korff Metal, pain, August 1992. Grade 0-No pain and no disability. Grade 1-Low disability-low intensity. Grade 2-Presence of pain/low disability-high intensity. Grade 3-Moderate pain/high disability-moderately limiting. Grade 4-Severe pain/high disability-severely limiting

Table 2: Spinal/local examination

\begin{tabular}{|c|c|c|c|}
\hline Serial number & 02.12.2015 (Grade) & 06.01.2015 (Grade) & $\begin{array}{l}\text { Follow-up on } \\
05.02 .2016\left(1^{\text {st }}\right)\end{array}$ \\
\hline Inspection & $\begin{array}{l}\text { Not able to put leg on floor (painful gait), } \\
\text { posture-comfort on sleeping, discomfort with standing } \\
\text { and walking, presence of lumbar scoliosis disappeared } \\
\text { on sitting, flat lumbar region, presence of longitudinal } \\
\text { scarring of previous spinal surgery, axial loading-absent }\end{array}$ & $\begin{array}{l}\text { Gait-normal } \\
\text { posture-ambulatory lumbar } \\
\text { scoliosis+with flat lumbar } \\
\text { region }\end{array}$ & $\begin{array}{l}\text { Gait-absolutely normal } \\
\text { posture-ambulatory lumbar } \\
\text { scoliosis+with flat lumbar } \\
\text { region }\end{array}$ \\
\hline Palpation & $\begin{array}{l}\text { No localized tenderness, tenderness on L4-L5 area on } \\
\text { leaning forward }\end{array}$ & No localized tenderness & No localized tenderness \\
\hline Percussion & No tenderness on percussion & No tenderness on percussion & No tenderness on percussion \\
\hline \multirow[t]{4}{*}{ Movement } & Restriction of flexon of LS spine $(3 \mathrm{~cm})$ & $\begin{array}{l}\text { Restriction of flexon of LS } \\
\text { spine }(5 \mathrm{~cm})\end{array}$ & $\begin{array}{l}\text { Restriction of flexon of LS } \\
\text { spine }(6.5 \mathrm{~cm})\end{array}$ \\
\hline & Schober's test $-3 \mathrm{~cm}$ at LS joint & $\begin{array}{l}\text { Schober's test- } 5 \mathrm{~cm} \text { at } \mathrm{LS} \\
\text { joint }\end{array}$ & Schober's test- $6 \mathrm{~cm}$ at LS joint \\
\hline & Extension of spine limited to $25^{\circ}$ & Extension of spine range & Extension of spine range from \\
\hline & $\begin{array}{l}\text { Rotation of Lumbar joint range from } 3^{\circ} \text { to } 5^{\circ} \text { thoracic } \\
\text { movement within normal limit }\end{array}$ & $\begin{array}{l}\text { from } 25^{\circ} \text { to } 35^{\circ} \text {, rotation of } \\
\text { lumbar joint range from } 3^{\circ} \\
\text { to } 5^{\circ}\end{array}$ & $\begin{array}{l}25^{\circ} \text { to } 35^{\circ} \text {, Rotation of Lumbar } \\
\text { joint range from } 3^{\circ} \text { to } 5^{\circ}\end{array}$ \\
\hline \multicolumn{4}{|l|}{ Special tests } \\
\hline \multirow[t]{2}{*}{ SLR } & Right leg $\left(30^{\circ}\right)$ & Right leg $\left(75^{\circ}\right)$ & Right leg $\left(90^{\circ}\right)$ \\
\hline & Left leg $\left(15^{\circ}\right)$ & Left leg $\left(75^{\circ}\right)$ & Left leg $\left(80^{\circ}\right)$ \\
\hline Bowstring test & Negative & Negative & Negative \\
\hline \multirow[t]{2}{*}{ Lasegue's sign } & Right leg (+) & Right leg $(-)$ & Right leg $(-)$ \\
\hline & Left leg $(++)$ & Left leg $(-)$ & Left leg $(-)$ \\
\hline FNS test & Negative & Negative & Negative \\
\hline Neurological & Numbness/hypoesthesia on dorsolateral area (left foot) & No such sign witnessed & No such sign witnessed \\
\hline Others & Features of degenerative changes of both knee & Pain improved & Pain much improved \\
\hline
\end{tabular}

FNS: Femoral nerve stretch, SLR: Straight leg raise 
5. Vatashamaka and Rsayana Oushadhi Sevana (Rasnadi Guggulu $1 \mathrm{~g}$ tds, Trayodashang Guggulu $1 \mathrm{~g}$ tds, Maharasndi Kwatham $15 \mathrm{ml}$ bid ac, Sahacharadi Kshayam - $15 \mathrm{ml}$ bid ac, Vishatinduka Vati - $125 \mathrm{mg}$ tds, Triphala Churna $6 \mathrm{~g}$ at hs sos, and Aswagandhadi Lehyam $10 \mathrm{~g}$ bid) for 1 month.

\section{Self-care}

Avoiding bending forward and lifting heavy weights, to do core back strengthening exercises, light work for another 6 months.

\section{Discharge summary and Follow-up}

PR-80/minutes, no pallor, gait-normal, spine examination: No list/ deformity, no swelling/scar/sinus, no tenderness, ROM-pain free and full, B/L SLR-negative, no distal neurological deficits, Hb\%-13.6, platelet count-161,000/cumm, PT-10.7 seconds, activated partial thromboplastin time-36.4 seconds, liver function test: Within normal limit, serum creatinine-0.97, random plasma glucose-118 mg/dl, HIV-negative, hepatitis B surface antigen-negative, hepatitis C virusnegative. No significant changes in X-ray of dorsal and LS spine. The patient was followed up on each day of therapy for improvement as well as for any adverse effect and assessed only on the day of discharge and after 1 month. No adverse effect was reported by the patient nor assessed during treatment. Changes in intensity of pain and changes in the examination of the spine were documented (Tables 1 and 2).

\section{DISCUSSION}

Lumbar stenosis is not uncommon disease affects usually after the age of 50 and causes gross morbid changes in the locomotor system. In younger subject, genetic factors are the reason. In the case in discussion, dhatukshaya due to Jara (aging) and trauma are the responsible etiological factors. Atichinta (stress) is also the pathognomonic factor in the genesis of the disease. All the causes vitiated the vata dosa and leading to kshayajanya (degenerative) and sankocha (compression) related symptoms. Untreated case of lumbar stenosis can cause morbid conditions, paralysis, and incontinence. In routine practice, activity modification, spinal exercises, and NSAIDs are usually prescribed, and lumbar laminectomy is the last option as surgical treatment of the disease. In Ayurveda, vata vyadhi is treated by sodhana (snehana, swedana, vasti), shamana (drugs possess Madhura-amla-lavan-snigdha properties), and nidana parivarjana (avoidance of etiological factors).

Abhyanga mentioned under external (snehana) oleation therapy, directly acts on muscles and makes them strong. The root of Mamsavaha Srotas is Snayu (ligaments), Tvacha (skin), and Raktavahini (blood vessels). So here, Abhyanga is done over Tvacha and Snayu, and also it involves Raktavahini. Direct benefit is achieved at Mamsavaha Srotas. Abhyanga nourishes deeper Dhatus also. Here, one thing we can say that Abhyanga makes the muscles strong and thus keep the joints stable $[7,10]$.

Swedana is Sandhichestakar (improvises the movements of joints), srotoshuddhikar (clears up the micro channels), Agni Deepaka, and Kaphavatanirodhan (antagonist of Kapha). It decreases Stambha (stiffness). Heat administration by Swedana may produce hypno analgesic effect by diverted stimuli. In sandhigatavata, sanga type of srotodushti is present swedana, by doing srotoshuddhi, this sanga is relieved [11].
Kativasti involves retention of warm medicated oil over the affected part of spine for certain period. It alleviates pain, numbness, strengthens the back muscles, maintains the curvature of spine, reduces stiffness, and increases blood circulation of the region. It also nourishes the muscle and nerve [6].

All the therapy used in the case aimed at reducing the pain, stiffness, improvement of muscle power, strengthening of spinal muscles, and correction of spinal curvature.

Indigenous compound drug used it has properties such as vedanasthapana (analgesic), shothahara (anti-inflammatory), balya, rasayan, sandhaniya, deepana, and anulomana. Its pharmacological activities include anti-inflammatory, analgesic, antioxidant, and immune-stimulant. By these properties, this drug is beneficial for the shaman of sandhigatavata [12]. The limitation of the study is that post-treatment imaging of LS spine could not be done as no significant changes in radiology of LS spine is observed.

\section{RECOMMENDATION}

The current study is about the presentation of the single case only. Moreover, a well-structured, standardized, randomized, clinical trial is recommended.

\section{ACKNOWLEDGMENT}

We are thankful to the subject for hisco-operation during the study and also for giving consent to publish the data.

\section{REFERENCES}

1. Lee SY, Kim TH, Oh JK, Lee SJ, Park MS. Lumbar stenosis: A recent update by review of literature. Asian Spine J 2015;9(5):818-28

2. Fritz JM, Lurie JD, Zhao W, Whitman JM, Delitto A, Brennan GP, et al. The associations between physical therapy and long-term outcomes for individuals with lumbar spinal stenosis in the SPORT study. Spine J 2014;14(8):1611-21.

3. Sajitha K. An insight in to "KATIGRAHA" (Low Back Ache). Anc Sci Life 2001;21(1):16-7.

4. Singh SK, Rajoria K. Ayurvedic approach in the management of spinal cord injury: A case study. Anc Sci Life 2015;34(4):230-4.

5. Srujani MS, Dash NC, Das BK. A clinical study on Gridhrasi (Sciatica) and its management with Nirgundi. J Res Ayurveda Siddha 2003;24(1-2):42-50.

6. Bali Y, Vijayasarathi R, Ebnezar J, Venkatesh B. Efficacy of Agnikarma over the padakanistakam (little toe) and Katibasti in Gridhrasi: A comparative study. Int J Ayurveda Res 2010;1(4):223-30.

7. Joshi A, Mehta CS, Dave AR, Shukla VD. Clinical effect of Nirgundi Patra pinda sweda and Ashwagandhadi Guggulu Yoga in the management of Sandhigata Vata (Osteoarthritis). Ayu 2011;32(2):207-12.

8. Von Korff M, Ormel J, Keefe FJ, Dworkin SF. Grading the severity of chronic pain. Pain 1992;50(2):133-49.

9. Calcitonin S, Spray N, Purohit I. Assessment of efficacy, safety and quality of life in postmenopausal women with osteoporosis using Salmon calcitonin nasal spray. Asian J Pharm Clin Res 2013;6(2):4-6.

10. Bhat DD, Aithal P, Kumar V, Deva S. A clinical study on Jatamayadi Upanaha Sweda in Janu Sandhi Gata Vata (osteoarthritis of knee joint). J Holist Med 2015;3(6):10-8.

11. Singh SK, Rajoria K. Ayurvedic approach in the management of spinal cord injury: A case study. Anc Sci Life 2015;34(4):230-4.

12. Patwardhan SK, Bodas KS, Gundewar SS. Coping with arthritis using safer herbal options. Int J Pharm Pharm Sci 2010;2(1):1-11. 